\title{
Martin Buber's Dialogical Communication: Life as an Existential Dialogue
}

\author{
VAIDA ASAKAVIČIŪTE் \\ Department of Entertainment Industries, Vilnius Gediminas Technical University, 1 Trakų Street, 01132 Vilnius, Lithuania \\ Email: vaida.asakaviciute@vgtu.lt
}

VYTIS VALATKA

Department of Philosophy and Cultural Studies, Vilnius Gediminas Technical University, 1 Trakų Street, 01132 Vilnius, Lithuania Email: vytis.valatka@vgtu.lt

\begin{abstract}
On the basis of Martin Buber's philosophy, the article analyses the links between the dialogue and human existence. In the beginning of the first part, the definition of Buberian dialogue is analysed from the perspective of relation. This perspective shows that primary relations may be of twofold character because there is a constant fight between the two $I$ and $I t$. This shows that human existence is not static and undergoes a gradual development. It is also under constant evolvement and faces a choice. Consumer society and mass media are said to contribute to gradual establishment of the relation I-It, which results in a loss of direct interpersonal communication. In the second part of the article on the basis of the opposition between the dialogue and monologue, different ways of human existence are discussed. The opinion that a dialogic relation is a means for an individual to ascend from the inauthentic to authentic dimension of existence is substantiated. Thus, approaching a dialogue from the perspective of Buber's dialogic communication, it does not have a well-defined structure or any universal models. It is the experience lived through in an intuitive and unique way. In this respect, the dialogue remains the goal and mystery of person's existential life.
\end{abstract}

Keywords: Buber, dialogic communication, dialogue, monologue, existence, relation I-Thou and I-It

\section{INTRODUCTION}

Our world is hyper-mediated by technology and this changes not only the relation of a person with the surrounding world but also relations among people (Zimmermann, Morgan 2019: 43). It can be stated that Cyber Culture is gaining ground when computers and mobile phones have become an integral part of human existence. Media and social networks create a need for easy and fast communication (Kačerauskas 2019). Therefore, in the era of prevailing social networks, when virtual communication in the electronic space is becoming more and more established, the problem of interpersonal communication and a direct as well as an authentic dialogue is becoming particularly important and urgent. Sylwia Górzna (2014) 
presents Martin Buber as the father of philosophy of dialogue, whose texts contain the roots of dialogic philosophy. In his reflections on human existence, Buber, as a representative of existentialism, placed a particular attention to communicative aspects of human existence. Buber's philosophy of dialogue is widely analysed from the perspectives of various social sciences and humanities: theology (Cohen 2019; Marbun 2019, Cooper 2018); sociology and cultural studies (Zmmermann, Morgan 2019; Serena, Miles 2019); pedagogy (Tsabar 2019; Soares et al. 2019; Lawrence 2019); psychology (Chávez et al. 2019; Starovoytenko 2017); communication (Stewart, Kellas 2020; Brown, Hersey 2019) and philosophy (Rubskyi 2019; Bralgin 2017). In the context of the previous studies, it is possible to state that 'Martin Buber's ontology of relationship can be considered one of the most important and significant theories of dialogue' (Tumminelli 2016: 133). Buber substantiated an inseparable link between the life and the dialogue and in his works elaborated on the unique theory of human life as an existential dialogue. The research in Buber's dialogic communication is important and relevant to an individual living in the information age. These investigations point to the authentic human dialogue, open a new glimpse at the importance and meaning of the dialogue in people's life.

The aim of this article is to analyse the essence of dialogue as a primary relation and its significance to human existence, to reveal peculiarities of the authentic I-Thou as direct interpersonal communication, highlighting the opposition of the monologue I-It and pointing out the reasons for losing an existential dialogue following Buber's texts. The author begins with showing the importance of a dialogue in a relation and underlines the dissimilarity between Buberian I-It and I-Thou. Then the article describes the difference between the dialogue and the monologue in the context of contemporary life. Finally, the conclusions pinpoint the contemporaneity of Buber's thought on a dialogical communication, giving a detailed recapitulation of the aforementioned issues.

\section{DIALOGUE AS RELATION: I-IT VERSUS I-THOU}

The relation becomes the starting point in Buber's dialogue thinking. According to Buber, 'in the beginning is relation' (Buber 1998: 88). Without an opportunity to establish relations with another person, human existence loses its meaning and completeness. Thus, raising the question about the essence of Buberian dialogue, it is firstly necessary to discuss the relation itself because the dialogue is only possible in the relation, where the meeting takes place. Through the relation an individual participates in, perceives, experiences and accepts the dialogue. Therefore, the dialogue is essential for relationship (Genu et al. 2019). In his work 'I and Thou' (1998) Buber refers to three spheres in which the world of relation arises: the first one includes life with nature; the second refers to life with men and the third sphere is related to life with intelligible forms. So apart from being a philosopher of dialogue, Buber can also be seen as a philosopher of relationships with nonhuman things (for example, craft and artistic creation) (Dustin 2019) and nature (creation). This attitude inspired new views on modern ecological and environment problems (Jank 2018).

The relation in Buber's philosophy turns into an opportunity for an individual to learn and participate in the reality. In other words, human existence is in a constant relation: 'the effort to establish relation comes first' and it manifests itself as early as babyhood, when a child feels a natural desire to be in a constant relation, to seek for companionship, communication and touching another person (Buber 1998: 97). And further: 'in the beginning is relation - as category of being, readiness $\langle\ldots>$ mould for the soul; $\langle\ldots\rangle$ as the inborn Thou' (Buber 1998: 97). The relation is the starting point of dialogue. Thus, the relation cannot be 
separated from the dialogue and the dialogue cannot be separated from existence. Tomas Sodeika notices that the dialogue, which is referred to by Buber, is not so much of an exceptional kind of activity, which differs from any other kinds of activities, but rather a universal way of being that embraces any activity and any existence' (Sodeika 2001: 42). This insight allows stating that a dialogue is deeply rooted in the human existence: 'the foundation of all relationships is the need to belong, to love, and to be appreciated and valued in return' (Deurzen 2009).

Seeking to highlight the links of relation, dialogue and existence, in his main work 'I and Thou' (1923) Buber distinguishes two primary relations I-Thou and I-It. It is obvious that the analysis of these two primary relations comprise the essence of the Buber's dialogic communication theory. Only the relations I-Thou make it possible for a dialogue to be born and for this reason the former are prioritised by Buber.

Thus, from the perspective of Buber's existential philosophy, the dialogue is approached as an integral part of person's life and these two relations I-Thou and I-It together point to two different states of human life, i.e. authentic - dialogic existentialist being and inauthentic-monologic existentialist being. The division between the authentic and inauthentic existence is visible in the philosophies of the majority of existentialists, such as Soren Kierkegaard, Martin Heidegger, Ortega y Gasset, Georg Simmel and others. Existentialists are said to be concerned about what brings an individual closer to authentic existence and opens it (Kačerauskas, Véželis 2016; Holub 2019). Buber's dialogic communication philosophy was strongly influenced by the religious worldview of Danish thinker Kierkegaard. Although the concept 'existence' was not directly used in his texts, the main leitmotivs of thinking were closely interrelated with the tradition of existential thinking (Karl Jaspers, Juozas Girnius, Martin Heidegger, Jean-Paul Sartre) and 'life philosophy' (Friedrich Nietzsche, Wilhelm Dilthey, Georg Simmel), where considerable attention is allocated to addressing the issues of meaningfulness and authenticity of human life.

Following the texts of Buber, it is possible to justify the radical difference between the relations I-Thou and I-It. From the comparative aspect, the first type of relations I-Thou indicates freedom of individuals, their equality and acknowledgement of individual differences. The second type of relation I-It includes a material posture towards another person, which unfolds the loss of personalism and openness with the Other. It is important to draw attention to the fact that 'the $I$ of the primary word $I$-Thou is a different one I from that of the primary word I-It' (Buber 1998: 69). In the first case I remains egoistic and self-centred, in the second case $-I$ is giving himself or herself away to others. According to Antonio Garcka (2015: 423-438), 'the I-It characterises relations with objects (things, ideas), but this attitude can be directed towards another person as an object seeking to manipulate him and abuse pursuing own goals. Thus, the relation I-It in the philosophy of Buber discloses the human existence, which is not a dialogic life at all but rather a superficial and insular life, which leads to loneliness and alienation.

Buber notices that these materialistic, pragmatic and non-dialogic relations I-It start to prevail in the consumer mass society, where 'a consumer and user I dominates'. The philosopher emphasises the state of relationshipless, which pervades in the mass society. Mass people exist as unrelated human units, alienated and anonymous and they are only guided by their selfish needs and instincts. However, it is necessary to rely on the soul, which is the centre of human essence and the foundation of genuine feelings. 'If they abjure spirit they abjure life', Buber writes (1998: 116). 
In the age of technological progress and rationalism, an individual is getting further and further away from the spirituality, which is concealed by materialism. The relation $I-I t$ starts dominating in interpersonal relations and it focuses on pragmatism and consumerism. 'The consumption of technologies forces us to follow elementary instructions that get transferred into the sphere of human relationships or the consumption of life' (Kačerauskas 2015: 856). Thus, means of mass communication considerably contribute to establishment of the relation I-It. Mass media encourage tendencies of uniformity (Kačerauskas 2018: 112), various communication methods, which have to be followed if one wants to be accepted and noticed in the social space, have been gaining ground (Mazur, Duchliński 2020). 'Facebook and Twitter trends with their superficial attraction become as contemporary forms of human contact' (Zimmermann, Morgan 2019: 35). Thus, human relations in the virtual space lose their spiritual cosiness, accessibility; an individual is deprived of the relation with 'real faces'. Arie Kizel (2019: 43) notices that young people think that the virtual space and WhatsApp are technological constructs, which create an opportunity to establish a dialogue-based relation I-Thou.

Thus, technological interfaces modify the individual's relation with the surrounding world and another person. An individual gets used to controlling and managing the process of communication, to keeping distance and maintaining security. 'Technology has increased our possibility of making initial contact with each other through new facilities and possibilities. However, it should not replace actual meetings that cannot be controlled or edited' (Zimmermann, Morgan 2019: 35). According to Buber (1998), the authentic dialogue I and Thou is the one, where the soul lies.

I-It signalizes not only the crisis of human relations but also that of human existence. According to Buber, 'this is the exalted melancholy of our fate $\langle\ldots$. , when every Thou in our world must become an It. Then, the Thou becomes an object among objects, fixed in its size and its limits' (1998: 87). The relations I-It show that an individual loses own identity and ceases to live own full meaningful life because if one lives and only pays attention to $I t$, he or she is not fully a man' (Górzna 2014: 446).

Buber emphasizes the necessity of dialogic relation and its importance not only to human existence but also to society, culture and history. The relation ensures renewal of these three spheres and their movement forward. Without this relation they get petrified and die. Hence, in the context of Buber's existential philosophy, the dialogic relation is a means, which enables an individual to know himself and the surrounding world. This is also an opportunity for him or her to discover the $I$. 'The person becomes conscious of himself as sharing in being, as co-existing, and thus as being $\langle\ldots$. , a person makes his appearance by entering into relation with other persons' (Buber 1998: 130-131). This shows that an individual is a creature that exists only together with others. This leads to the conclusion that a person for Buber is not self-sufficient, 'there is no $I$ taken in itself, but only the $I$ of the primary word $I$-Thou and the $I$ of the primary word I-It' (Buber 1998: 70). Thus, a person always faces a choice who to become: because $I$ becomes the real I only uttering Thou. If a person succumbs to own individuality and rejects Thou, who stands in front of him, he loses himself and sinks into unreality. John Stewart and Jody Koenig Kellas (2020) point: 'Martin Buber claimed that the capacity to experience uniqueness in verbal-nonverbal talk is an important part of what makes us human.'

One more important aspect becomes obvious in this context - that is, the duality of human existence. Buber writes: 'the world of man is twofold $\langle\ldots$. , every man lives in the twofold $I$ (1998: 132). Thus, there is a twofold situation in human existence. What does this 
mean? Following Buber's texts, it can be stated that there exists a constant opposition and fight between those two primary relations. According to Buber, a human life is a never-ending interchange from Thou to It and again to Thou. This means that human existence is not static, it undergoes indispensable and continuous changes, tension and swinging between the monologic and dialogic states. The man 'knows that his mortal life swings by nature between Thou and It' (Buber 1998: 119). This gives a rise to inner struggle and building up of values and worldview. A person, who perceives the truth of existence, becomes free, 'he is aware of the significance of this swing, which is inseparable from the purport and aim of the very life. 'The worst is that the world of It overpowers man $<\ldots>$ and the world of objects succumbs him' (Buber 1998: 121). Therefore, efforts and responsibility are necessary to create a dialogue, to accept a dialogue and to experience it. A person's decision, his inner attitude of soul, openness and sincerity acquire importance. All this becomes a prerequisite for relation and an opportunity for a dialogue in the human existence. According to Richard Johanessen, 'the dialogue seems to represent more of a communication attitude, principle, or orientation than a specific method, technique, or format' (Johanessen 1971, 374). Thus, Buber's dialogic communication can be related to ethic communication and it encourages people to return to the relation $I-T h o u$, to a deeply close dialogic relation. In Buber's words, this is fulfillment of human existential purpose.

\section{THE LEVELS OF BUBER'S DIALOGIC COMMUNICATION: DIALOGUE VERSUS MONOLOGUE}

Seeking to highlight the spiritual dimension of the dialogic relation and inner ontological expression, in his work 'Dialogue', Buber discusses three different types of dialogues, i.e. a genuine dialogue, a technical dialogue and a monologue. It can be stated that these three types together reveal certain different forms of communication. 'And even though a dialogue is often perceived as a synonym of communication, depending on the perspective of approaching it, a dialogue may disobey the usual order of communication' (Gutauskas 2010: 13). According to Ronald C. Arnett et al. (2008), Buber's dialogue is an 'enlarged communicative mentality'. Buber approached communication from the perspective of human relations. This perspective particularly binds communication, human life and allows revealing the foundations of interpersonal communication (Duck, McMahan 2012; Arnett et al. 2008; Anderson, Cissna 2008). It can be stated that Buber's philosophy of dialogue 'becomes, an existential praxis that involves all the concrete aspects of a person's life, being at the same time embodied in the relationships that everyone lives in their own community life' (Tumminelli 2016: 133).

The first, i.e. the genuine dialogue, described by Buber, can be referred to as the supreme level of interpersonal communication. Discussing this dialogue, the philosopher distinguishes its most relevant qualities: immediacy, mutuality, sincerity, equality and spiritual closeness of souls. The genuine dialogue does not require words and can mean just two people being in silence. Buber also mentions the dialogue silence. Silence occupies a significant place in the existential theories of Heidegger and Sartre. The silence provides with an opportunity to have a different glimpse at the world and to accept it. Yegor Bralgin (2017) notices that silence means the indication of a dialogue for Buber. This evidences that in the existential dialogue it is not the very moment of speaking that matters. It is more the meeting and internal spiritual listening to others that make up the core of it. All this discloses the contour of Buber's dialogic communication, which is closely linked with life.

The second type of dialogue - the technical dialogue - arises only from the urgent need to achieve objective understanding striving for mutual benefit. In Buber's texts this kind of 
dialogue is also determined as 'soulless dialogue'. It is grounded on mind, certain external rules and targets defined goals. This technical level of dialogue can also be regarded as certain business communication, the efficiency of which can be measured applying the established criteria and achieved results. It can be stated that the technical dialogue builds up partnership rather than friendship. Partnership is a concept of business rather than life. Well-defined strategies of communication and negotiation are characteristic of business situations (Markova et al. 2020; Kačerauskas 2019).

The third type includes the monologue disguised as a dialogue. A certain paradox can be envisaged here - although a monologue engages another individual, mutual communication does not occur in this situation. This happens because, according to Buber, a monologue does not derive from the necessity to announce anything, or from the need to communicate with somebody. A monologue occurs only because of a person's desire to confirm himself. 'Everyone talks to himself' in the monologue (Buber 2001: 71). Thus, a monologue can be regarded as an anti-dialogue.

Fagg Lawrence (2008: 236) states that 'Buber helps us understand the nature of true dialogue by cogently describing what I-Thou dialogue is not.' Thus, seeking to better understand the genuine dialogue, it is necessary to elaborate on the essence of the monologue. 'In the monologue a person is interested only in himself, he sees and hears only himself' (Buber 2001: 77). So 'a monologue exists when you simply monopolize the conversation' (Littlejohn et al. 2017: 244). Such a position of an individual reveals that a dialogue does not happen because an individual turns away from the other and refuses to accept the other as an equal person. This position is confirmed by the fact that the main word in the monologue is $I$ : what $I$ feel, what $I$ want, what $I$ seek for. The other person in the monologue does not mean anything because Thou does not exist anymore. Therefore, according to Buber, the monologue only creates an external image of a friendly dialogue but here 'the dialogue turns into a mere appearance, a performance' (Buber 2001: 77).

In his works Buber analyses why the monologue I-It starts to prevail in human relations. Firstly, it is related to egocentrism. 'The $I$ of the primary word I-It makes its appearance as individuality (ego)' (Buber 1998: 130). Self-centeredness in relations is like a wall, which separates an individual not only from others but also from himself. In Buber's opinion, a self-centred person cares only about himself, seeks to take advantage of others and appropriate them. With such an inner attitude an individual separates himself from the others around him and, although he lives next to others, he remains alone and alienated. Therefore, the principle of self-differentiation seeking to take as much as possible from him, and self-differentiation, according to Buber, is dying 'that lasts the span of a man's life' (Buber 1998: 130). The attitude of an individual in the dialogue is absolutely different and mutual giving becomes a key concept here. When 'you say Thou to it and give yourself to it, it says Thou to you and gives itself to you' (Buber 1998: 103). Differently from the monologue, the word Thou is the key word in the dialogue. According to Sodeika (2001), Buber substantiates his own dialogic philosophy by this primary word, i.e. by the personal pronoun Thou. But only 'when Thou is spoken, the speaker takes his stand in relation' (Buber 1998: 71). Attaching a significant attention to inner communication, Buber argues that the spoken word Thou does not mean anything as it can only be seen as a manifestation of hypocrisy because uttering Thou a person means nothing else in a serious way but to experience and make use of (Buber 1998: 104). The other should be addressed speaking 'from the being' (Buber 1998: 70). A person, his soul, life, experience and responsibility for the other have to be fully incorporated into the dialogue. Such an attitude 
provides a dialogue with an existential, spiritual level. 'The dialogue is not only a physical conversation of two people but also an attitude of soul - a certain ontological mystery, hidden from the others $<\ldots>$ mysterious communication of one person's world with that of the other person' (Buber 2001: 77). Hence, while analysing Buber's relations I-Thou, Elena Starovoytenko (2017) refers to them as to 'life relations' and 'the dialogue of life'.

According to Buber, preconception or prejudice about a person we communicate with provides another important reason, which prevents a person from engaging into a living dialogue. Arie Kizel (2019: 19) notes that 'if a person has any expectations or prejudices before starting a conversation, this stops the emergence of a dialogue.' Similar ideas were also expressed by Teresa Żółkowska (2013). According to her, one of the requirements for a genuine dialogue to happen is to accept another individual as different and perceiving that who he is does not depend on my opinion or attitude towards him. Thus, a dialogue unfolds only in freedom, where there are no prejudices. The dialogue is a relation and a meeting. And 'an event of meeting is detached from knowing, using, consuming, satisfaction and other practical and theoretical dimensions' (Gutauskas 2010: 214). Thus, the diversity and identity are together expressed through the dialogue (Mickūnas, Kačerauskas 2020: 236).

Buber raises one more relevant issue, which results in a loss of authentic dialogue and is related 'to the problem of being and seeming', when in the process of communication a person cares only about the impression he makes on other people. What does this mean? Michael A. Brown et al. (2019: 71) states that Buber draws a distinction between 'being' and 'seeming. He argues that there are two types of human existence. The first comes from what it really is, the other from what one wishes to seem. 'Seeming' has two forms: first, 'genuine seeming' and, second, inauthentic seeming. Górzna (2014: 47) supplements this insight pointing out that 'an individual, who meets another individual, may create three images: the first one may show how he wants to present himself, the second may show how he really presents himself and the third image discloses who he really is'.

In the communication and internet society a lot of attention is paid to image communication. It is emphasized that the created image is a means of making influence on the surrounding people and their decisions. Life turns into 'theatre of everyday life' shaped by television and photography technologies (Serena et al. 2019; Lasch 1991). Buber envisages a danger here. He states that human existence is put at a risk because human relations and life are full of pretence and permeated with the untrue. 'The true in the interpersonal relations means that people give themselves to each other the way they are in real' (Buber 2001: 174). Thus, in the context of the analysis of dialogue versus monologue, different ways of human existence are unfolded. 'The first [dialogic] one may be defined as fundamental life, the life, which is predetermined by the fact that a person is who he is, whereas the second [monologic] is life based on the image, the life, which is resulted in by what a person wants to seem' (Buber 2001: 172).

Buber states that 'dialogic life - is $<\ldots . .>$ the life, where we encounter people in real' (Buber 2001: 72). The reference to 'in real' shows authenticity and truth, sincerity and openness. Thus, seeking to be what he is not, a person loses identity and authenticity and becomes It. The other Thou becomes 'as if a mirror', which helps a person to see and perceive himself: 'The $I$ does not exist without the Other and can say nothing about itself without looking at the Other as a sort of living mirror' (Starovoytenko, Derbeneva 2017: 366).

Thus, a dialogue in Buber's existential philosophy becomes a matter of inner experience and highly individual experience. This attitude is close to Jaspers' existential communication. This allows arriving at a significant conclusion that Buber's dialogue is a mystery, which lacks 
well-defined and static structure. Since the essence of dialogue cannot be determined structurally, 'it cannot be explained employing laws of the communication process' (Gutauskas 2010: 207). The expression of dialogic communication, which occurs between two people, in each case is subjective, exceptional and non-repetitive. It is namely the dialogue that makes every interpersonal communication very unique (Stewart, Kellas 2020). Thus, in the context of Buber's dialogic communication, the dialogue may be regarded as the aim and purpose of human existence.

\section{CONCLUSIONS}

After a brief discussion of the conception of Buber's dialogic communication, it can be stated that Buber allocated an exceptional attention to communicative aspects of human existence. The philosopher approached communication from the perspective of life stating that a direct relation $I$-Thou plays a crucial role in human existence. Moreover, the conception of Buber's communication as a dialogue is built on the opposition between the dialogue and monologue. In this context the importance and relevance of Buber's insights into contemporary media and technology society, which is gradually moving away from the authentic dialogue, interpersonal relations are replaced by virtual communication, where an individual hides behind an externally created image. Another important aspect that arises from the analysis of Buber's dialogic communication is related to the duality laying in the human existence, i. e. an individual is always exposed to a choice: either he steps into authentic existence, opening up to another individual through the relation, or turns away from another individual and will remain in the restricted and egoistic world, i.e. in inauthentic existence. And finally, the dialogue, which is referred to by Buber, is a life dialogue distinguished by its uniqueness and individuality. It lacks universal schemes, methodology or external criteria and, therefore, cannot be unambiguously defined. Therefore, it can be stated that Buber's dialogic communication opens up a dialogue as a mystery of human existence. The essence and goal of this dialogue is the very being of two individuals together, closeness of their souls rather than a certain overall achieved result.

Received 15 December 2019

Accepted 11 February 2019

\section{References}

1. Anderson, R.; Cissna, K. N. 2008. 'Fresh Perspectives in Dialogue Theory', Communication Theory 18: $1-4$.

2. Arnett, R. C.; Grayson, C.; McDowell, Ch. 2008. 'Dialogue as an "Enlarged Communicative Mentality": Review, Assessment, and Ongoing Difference', Communication Research Trends. A Quarterly Review of Communication Research 27(3): 3-25.

3. Bralgin, Y. U. 2017. 'On the Question of the Phenomenon of Silence in Existentialism. The Role of Dialogue', Tomsk State University Journal of Philosophy Sociology and Political Science 38: 56-62.

4. Brown, M. A.; Hersey, L. 2019. Returning to Interpersonal Dialogue and Understanding Human Communication in the Digital Age. United States of America: IGI Global Information Science Reference.

5. Buber, M. 1998. Dialogo principas I. AŠ ir TU. Vilnius: Katalikų pasaulio leidiniai.

6. Buber, M. 2001. Dialogo principas II. Dialogas. Klausimas pavieniui tarpžmogiškumo pradai. Vilnius: Katalikų pasaulio leidiniai.

7. Chávez, T. A.; Givens, J.; Lemberger-Truelove, M. E.; Lemberger-Truelove, T.; Palacios, A. F. 2019. 'Dialogical Meaning and Justice for Constructivist and Existential Psychologies', Journal of Constructivist Psychology 32(2): 138-147.

8. Cohen, J. 2019. 'Form and Content in Buber's and Schweid's Literary-Philosophical Readings of Genesis', Religions 10(6): 398-410. 
9. Cooper, D. E. 2018. 'Sense, Mystery and Practice', International Journal of Philosophy and Theology 79(4): 425-436.

10. Deurzen, E. 2009. Psychotherapy and the Quest For Happiness. London: Sage Publications Ltd.

11. Duck, S.; McMahan, D. T. 2012. Basics of Communication: A Relational Perspective. Thousand Oaks: Sage Publications, Inc.

12. Dustin, A. 2019. 'How to Do Things with Things: Craft at the Edge of Buber's Philosophical Anthropology', Images 12(1): 134-147.

13. Garcka, A. F. 2015. 'Beyond Theory: Martin Buber's I and Thou and the Role of Contemplation in Integrated Relational Counseling', Journal of Creativity in Mental Health 10(4): 423-438.

14. Górzna, S. 2014. 'Martin Buber Father of the Philosophy of Dialogue', European Journal of Science and Theology 10(5): 45-53.

15. Gutauskas, M. 2010. Dialogo erdvé. Fenomenologinis požiūris. Vilnius: Vilniaus universiteto leidykla.

16. Holub, G. 2019. 'Human Dignity: Between the Existentialist and the Essentialist Approaches', Philosphy. Sociology 30(3): 206-214.

17. Jank, A. 2018. Spotkanie człowieka z przyroda w myśli Martina Bubera. Available at: http://radykalnyslon.org/spotkanie-czlowieka-z-przyroda-w-mysli-martina-bubera/ (accessed 02.02.2020).

18. Johannesen, R. 1971. 'The Emerging Concept of Communication as Dialogue', Quarterly Journal of Speech 57: 373-382.

19. Kačerauskas, T. 2015. 'Technological and Economic Development of Economy', Technologies in Creative Economy and Creative Society 21(6): 855-868.

20. Kačerauskas, T. 2018. 'Castes and Classes in the Environment of Media from the Communication Discourses Point of View’, Logos 96: 109-117.

21. Kačerauskas, T. 2019. 'Ethics in Business and Communication: Common Ground or Incommensurable?', E+M Ekonomie a Management 22(1): 72-78.

22. Kačerauskas, T.; Věželis, T. 2016. Šiapusybès regionai: 50 Heideggerio filosofijos klausimų. Vilnius: Technika.

23. Kačerauskas, T. 2019. 'Alternative Schools of Communication: Philosophical Aspects', Tomsk State University Journal of Philosophy, Sociology and Political Science 49: 92-100.

24. Kizel, A. 2019. 'I-Thou Dialogical Encounters in Adolescents' WhatsApp Virtual Communities', AI \& Society 34: 19-27.

25. Lasch, C. 1991. The Culture of Narcissism: American Life in an Age of Diminishing Expectations. New York: Norton \& Company.

26. Lawrence, W. F 2008. 'Dialogue in Our Cosmic Aloneness', Theology and Science 6(2): 233-238.

27. Lawrence, P. 2019. 'Dialogical Agency: Children's Interactions With Human and More-thanhuman', European Early Childhood Education Research Journal 27(3): 318-333.

28. Littlejohn, S. W.; Foss, K. A.; Oetzel, J. G. 2017. Theories of Human Communication. United States of America: Waveland Press, Inc.

29. Marbun, S. 2019. 'Martin Buber's Theopolitics', Political Theology 20(4): 358-359.

30. Markova, M.; Modliński, A.; Pinto, L. M. 2020. 'Creative or Analitical Way for Career Development? Relationship Marketing in the Field of International Business Education', Creativity Studies 13(1): 99-113. 31. Mazur, P. S.; Duchliński, P. 2020. 'Credibility and Creativity in Network Society', Creativity Studies 13(1): 53-63.

32. Mickūnas, A.; Kačerauskas, T. 2020. Kūrybos komunikacija. Vilnius: Technika.

33. Rubskyi, V. M. 2019. 'Communication Levels of the Individual', Anthropological Measurements of Philosophical Research 16: 24-32.

34. Serena, C. L.; Miles, C. 2019. '(Selfie)ishness: Using the I-It/I-Thou Distinction to Parse an Ethics of Self-portraiture', Consumption Markets \& Culture 21: 1-5.

35. Soares, M. G.; Moreira, L. R.; Bentes, A. J. 2019. 'The Dialogic Relational Philosophy and Prospects of Interculturalism in Education', Revista Tempos e Espacos Educacao 12(30): 275-290.

36. Sodeika, T. 2001. „Dialogas ir tekstas“, in Martin Buber Dialogo principas II. Dialogas. Klausimas pavieniui. Tarpžmogiškumo pradai. Vilnius: Katalikų pasaulio leidiniai.

37. Starovoytenko, E. B. 2017. 'Productivity of the Dialogical Relationships I-Other', Psychology 14(3): 408-432. 
38. Starovoytenko, E. B.; Derbeneva, A. 2017. 'Resources of a "Conversation Partner" in a Dialogical I-Other Relationship', Psychology. Journal of the Higher School of Economics 14(2): 356-376.

39. Stewart, J.; Kellas, J. K. 2020. 'Co-constructing Uniqueness: An Interpersonal Process Promoting Dialogue', Atlantic Journal of Communication 28(1): 5-21.

40. Tsabar, B. 2019. 'On the Ambiguity of Teaching-relationship Ethics in Pedagogical Tutoring Work', Ethics and Education 14(1): 84-101.

41. Tumminelli, A. 2016. 'Dialogue and Community of Life in Martin Buber's Ontology of Relationship', Teoria-rivista di Filosofia 36(1): 133-149.

42. Zimmermann, A. C.; Morgan, W. J.; Forster's, E. M. 2019. 'The Machine Stops: Humans, Technology and Dialogue', AI \& Society 34: 37-45.

43. Żółkowska, T. 2013. 'Ja, Ty, Inny - dialog?', Studia Edukacyjne 28: 17-30.

VAIDA ASAKAVIČIŪTĖ, VYTIS VALATKA

\title{
Martino Buberio dialoginė komunikacija: gyvenimas kaip egzistencinis dialogas
}

\begin{abstract}
Santrauka
Straipsnyje, remiantis Martino Buberio filosofija, analizuojamos dialogo ir žmogaus egzistencijos sąsajos. Pirmoje dalyje apžvelgiama buberiško dialogo apibrèžtis iš santykio perspektyvos. Ši perspektyva parodo, kad gali būti dvejopi pamatiniai santykiai, nes žmogaus būtyje nuolat kovoja du pradai $A \check{s}$ ir Tai. Žmogaus egzistencija nèra statiška, tolygiai besivystanti, ji nuolat kinta ir yra pasirinkimų kryžkelèje. Teigiama, kad vartotojiška visuomenè ir masinès medijos vis labiau ịtvirtina $A \breve{s}-T a i$ santykius, kurie lemia tiesioginès tarpasmeninès komunikacijos praradimą. Antroje dalyje, remiantis dialogo ir monologo priešprieša, aptariami skirtingi žmogaus egzistavimo būdai. Pagrindžiama, kad dialogo santykis yra priemonè žmogui pakilti iš neautentiškos ị autentišką būties plotmę.
\end{abstract}

Žvelgiant iš M. Buberio dialoginès komunikacijos perspektyvos, dialogas neturi jokios apibrèžtos statiškos struktūros ar universalių modelių, jis - intuityviai ir unikaliai išgyvenama patirtis. Šiame diskurse dialogas išlieka žmogaus egzistencinio gyvenimo tikslas ir slëpinys.

Raktažodžiai: Buberis, dialoginè komunikacija, dialogas, monologas, egzistencija, santykis $A \check{s}-T u$ ir $A \check{s}-T a i$ 